\title{
KOMUNIKASI POLITIK PASANGAN CALON TUNGGAL TERHADAP PERILAKU MEMILIH MASYARAKAT KEFAMENANU PADA PILKADA 2015 DI KABUPATEN TTU PROVINSI NTT
}

\author{
Veki Edizon Tuhana, Pawito, Mahendra Wijaya \\ Program Studi Magister Ilmu Komunikasi Pascasarjana UNS \\ Email: vekiedizon@gmail.com
}

\begin{abstract}
The process of local elections is the right of every citizen to choose their leaders directly correspond confidence and the assessment of the candidates nominated by each party or coalition of parties, or running from an independent path to meet certain requirements. Concurrent local elections 2015 in Indonesia, which is in North Central Timor with a single candidate pair. Couples candidate election process is exciting because of the history of democracy and the political system of Indonesia for the first time carried out. This article is the result of research exploring: 1) analyzing the relationship between political communicator (single candidate pair) to the effects (voting behavior of society); 2) analyzing the relationship between the political message to the effect (voting behavior of society); 3) analyzing the relationship between media and interpersonal channels of the effect (voting behavior of society); 4) analyzing the relationship model of the sociological approach (religious affiliations and occupations) to the effects (voting behavior of society); As for the type of research is quantitative research with survey method. The study population was the whole community voters in District Kefamenanu City. The conclusions of the research and discussion is no relationship between political communicator with effect (voting behavior of society), there is a relationship between a political message to the effect, there is a relationship between the media and channels with effects, models sociological approach (religious affiliations and occupations) are not have a relationship with the effects.
\end{abstract}

Keywords: Political communication, single candidate pair, the public voting behavior

\begin{abstract}
Abstrak
Proses Pemilihan Kepala Daerah merupakan hak bagi setiap warga negara untuk memilih langsung pemimpinnya sesuai keyakinan dan penilaiannya terhadap calon yang diusulkan oleh masing-masing partai atau gabungan partai, atau yang mencalonkan diri dari jalur independen dengan memenuhi syarat tertentu. Pilkada serentak Tahun 2015 di Indonesia, salah satunya di Provinsi NTT, yaitu di Kabupaten Timor Tengah Utara (TTU) dengan pasangan calon tunggal. Proses pilkada pasangan calon tunggal merupakan hal yang menarik karena sepanjang sejarah demokrasi dan sistem politik Indonesia baru pertama kali dilakukan. Artikel ini merupakan hasil penelitian yang mengeksplorasi: 1) Menganalisis hubungan komunikator politik (pasangan calon tunggal) terhadap efek (perilaku memilih masyarakat); 2) Menganalisis hubungan pesan politik terhadap efek (perilaku memilih masyarakat); 3) Menganalisis hubungan media dan saluran interpersonal terhadap efek (perilaku memilih masyarakat); 4) Menganalisis hubungan model pendekatan sosiologis (agama yang dianut dan jenis pekerjaan) terhadap efek (perilaku memilih masyarakat); adapun jenis penelitian yang digunakan adalah penelitian kuantitatif dengan metode survei. Populasi penelitian adalah seluruh masyarakat pemilih
\end{abstract}


di Kecamatan Kota Kefamenanu. Adapun kesimpulan dari hasil penelitian dan pembahasan adalah ada hubungan antara komunikator politik dengan efek (perilaku memilih masyarakat), ada hubungan antara pesan politik dengan efek, ada hubungan antara media dan saluran dengan efek, model pendekatan sosiologis (agama yang dianut dan jenis pekerjaan) tidak mempunyai hubungan dengan efek.

Kata kunci: Komunikasi politik, pasangan calon tunggal, perilaku memilih masyarakat.

\section{A. Pendahuluan}

Komunikasi politik menurut para sarjana merupakan suatu fenomena yang terus berkembang dan melibatkan interdisiplin ilmu sosial antara lain ilmu komunikasi, politik, sosiologi, dan psikologi sosial.

Menurut Meadow (Pawito, 2009) komunikasi politik merupakan "segala bentuk pertukaran simbol atau pesan yang sampai pada tingkat tertentu dipengaruhi atau mempengaruhi berfungsinya sistem politik". Salah satu contohnya adalah proses komunikasi politik pada pemilihan kepala daerah (pilkada) serentak tahun 2015. Pemilihan kepala daerah adalah salah satu cara demokrasi yang dilakukan untuk mendapatkan kepemimpinan yang adil, bersih, jujur, berkompetensi, diselenggarakan secara transparan dan bertanggung jawab sesuai dasar hukum yang berlaku. Hal ini diatur dalam UndangUndang- Undang Nomor 8 Tahun 2012 tentang pemilihan umum Anggota Dewan Perwakilan Rakyat, Dewan Perwakilan Daerah, dan Dewan Perwakilan Rakyat Daerah (Pemilu) yang menyatakan pemilu adalah sarana pelaksanaan kedaulatan rakyat yang diselenggarakan secara langsung, umum, bebas, rahasia dalam Negara Kesatuan Republik Indonesia (NKRI) (diakses melalui www.dpr.go.id;tgl 11/09/2015).

Proses Pemilihan Kepala Daerah (Pilkada) bagi setiap warga negara mempunyai hak untuk memilih langsung pemimpinnya sesuai keyakinan dan penilaiannya terhadap calon yang diusulkan oleh masing-masing partai atau gabungan partai, atau yang mencalonkan diri dari jalur independen dengan memenuhi syarat tertentu sebagaimana 
diatur dalam Undang-Undang Nomor 8 Tahun Tahun 2015 tentang Pemilihan Gubernur, Bupati, dan Walikota ( UU Pilkada) Pasal (1) ayat (3) dan (4) (diakses melalui www.dpr.go.id;tgl 12/09/2015). Pilkada Tahun 2015 merupakan pilkada yang menarik karena dilakukan secara serentak di seluruh Indonesia dan semua daerah (269 daerah) baik di tingkat Provinsi, Kabupaten atau Kota berpartisipasi langsung (diakses melalui www.m.kompas.com;tgl 30/08/2015). Proses seleksi pilkada dilakukan oleh Komisi Pemilihan Umum Daerah (KPUD) menimbulkan fenomena baru di Indonesia yaitu adanya calon tunggal dalam pendaftaran pilkada serentak. Berdasarkan Peraturan Komisi Pemilihan Umum (PKPU) nomor 12 tahun 2015 mensyaratkan daerah harus diisi oleh minimal dua pasangan calon kepala daerah untuk dapat bersaing dalam proses pemilihan (diakses melalui http://m.cnnindonesia.com;tgl 02/09/15). Oleh karena itu daerah-daerah yang memiliki calon tunggal harus menunda pilkada Tahun 2015 dan baru akan melaksanakannya pada tahun 2017.

Berbagai pendapat mengatakan bahwa calon tunggal dapat diperbolehkan dengan cara mufakat dan aklamasi, walaupun pendapat lain menilai bahwa sangat mendadak karena Undang-Undang Nomor 8 Tahun 2015 tentang Pemilihan Gubernur, Bupati, dan Walikota yang mengatur tentang pemilihan kepala daerah baru disahkan beberapa bulan terakhir ini, sehingga tidak ada antisipasi terhadap berbagai hal seperti calon tunggal dan dualisme partai oleh UU pilkada tersebut serta keadaan tersebut sangat berdampak pada pelaksanaan pilkada (diakses melalui www.m.kompas.com;tgl 21/08/2015). Salah satu daerah dengan pasangan calon tunggal adalah Kabupaten Timor Tengah Utara (TTU) di Provinsi NTT. Pasangan calon tunggal yang bertahan adalah calon petahana Raymundus Sau Fernandes dan Aloysius Kobes, yang didukung oleh PDIP. Sedangkan dua pasangan calon yang tidak mendaftarkan diri ke KPUD (diakses melalui www.kompas.com;tgl 21/08/15). Pasangan calon tunggal petahana di Kabupaten TTU tidak dapat bersaing dalam pilkada Tahun 2015 karena tidak ada lawan politik yang mendaftar di KPUD. Dengan demikian sampai saat ini di Kabupaten TTU masih dipimpin oleh Bupati Raymundus Sau Fernandes karena masa jabatannya baru akan berakhir Tanggal 25 Desember 2015. Penundaan pilkada di Kabupaten TTU dinilai dapat menyebabkan masalah dalam proses pembangunan daerah, karena terjadi kekosongan pemimpin dalam menentukan dan menetapkan suatu kebijakan serta aturan-aturan dalam proses pembangunan. 
Proses pilkada pasangan calon tunggal merupakan hal yang menarik karena sepanjang sejarah demokrasi dan sistem politik Indonesia baru pertama kali dilakukan dan proses ini melibatkan diskusi yang panjang. Untuk itu pakar komunikasi politik Effendi Gazali dan Yayan Sakti Suryandaru mengajukan uji materi UU nomor 8 Tahun 2015 (diakses melalui www.m.kompas.com;tgl 29/09/2015). Uji materi menghasilkan putusan Mahkamah Konstitusi (MK) bahwa tiga daerah dengan pasangan calon tunggal diperbolehkan untuk mengikuti pilkada serentak Tanggal 9 Desember 2015. Dalam putusan MK tersebut, hakim mempertimbangkan bahwa "Undang-Undang mengamanatkan pilkada sebagai pelaksanaan kedaulatan rakyat untuk memilih kepala daerah, harus menjamin kekuasaan tertinggi di tangan rakyat" (diakses melalui www.m.kompas.com;tgl 29/09/2015). Walaupun pasangan calon tunggal, bukan berarti rakyat tidak mempunyai hak untuk menentukan pilihannya, karena MK memutuskan desain surat suara untuk rakyat memilih melalui kolom "setuju" dan "tidak setuju". (diakses melalui www.m.kompas.com;tgl 29/09/2015).

Putusan MK tentang pasangan calon tunggal untuk ikut pilkada, baru resmi diputuskan 29 September 2015. Selanjutnya 30 September 2015, KPU pusat mempelajari hasil putusan dan uji materi Undang-Undang Nomor 8 Tahun 2015 oleh MK untuk merubah Peraturan KPU (PKPU) Nomor 12 tentang Pencalonan dan Nomor 6 tentang spesifikasi surat suara (diakses melalui www.m.kompas.com;tgl 30/09/2015). Proses selanjutnya KPU melaksanakan rapat pleno dan rapat koordinasi dengan Badan Pengawas Pemilihan Umum (Bawaslu) dan Dewan Kehormatan Penyelenggara Pemilu (DKPP) yang membahas tentang pembentukan payung hukum untuk proses pilkada calon tunggal tanggal 7 Oktober 2015 (diakses melalui www.m.kompas.com;tgl 07/10/2015). Pilkada serentak 9 Desember 2015, hanya menyisahkan waktu satu bulan untuk proses komunikasi politik (kampanye) bagi pasangan calon tunggal petahana Raymundus Sau Fernandes dan Alosyus Kobes. Penelitian di Indonesia telah banyak dilakukan berkaitan dengan pasangan calon jamak dan menemukan temuan yang beragam, sedangkan belum ada penelitian mengenai komunikasi politik pasangan calon tunggal pada pilkada.

Berdasarkan latar belakang yang telah diuraikan di atas, maka permasalahan yang akan diteliti adalah sebagai berikut:

1. Bagaimana hubungan antara komunikator politik terhadap efek (perilaku memilih masyarakat)? 
2. Bagaimana implikasi hubungan pesan politik terhadap efek (perilaku memilih masyarakat);

3. Bagaimana implikasi hubungan media dan saluran interpersonal terhadap efek (perilaku memilih masyarakat)?

4. Bagaimana implikasi hubungan model pendekatan sosiologis (agama yang dianut dan jenis pekerjaan) terhadap efek (perilaku memilih masyarakat)?

\section{B. Metode Penelitian}

Penelitian ini merupakan penelitian kuantitatif dengan menggunakan metode survei. Tempat penelitian di Kecamatan Kota Kefamenanu dengan mencakup 6 (enam) Kelurahan yaitu Kefamenanu Utara, Kefamenanu Tengah, Kefamenanu Selatan, Benpasi, Aplasi dan Bansone. Populasi adalah seluruh masyarakat pemilih di Kecamatan Kota Kefamenanu. Sampel berjumlah 400 dengan teknik pengambilan sampel yaitu simple random sampling. Instrumen yang digunakan kuesioner dan pedoman wawancara mendalam (indepth interview). Data dianalisis secara univariat dan bivariat dengan Spearman Tes (SPSS versi $18)$.

\section{Hasil Penelitian dan Pembahasan}

\section{C.1. Hasil Penelitian}

\section{Analisis univariat}

a. Distribusi masyarakat pemilih berdasarkan variabel komunikator politik, pesan politik, media dan saluran di Kecamatan Kota Kefamenanu

Tabel 1. Distribusi Masyarakat Pemilih berdasarkan Komunikator Politik, Pesan Politik, Media dan Saluran Interpersonal di Kecamatan Kota Kefamenanu

\begin{tabular}{lcc}
\hline \multicolumn{1}{c}{ Variabel } & n & \% \\
\hline $\begin{array}{l}\text { Komunikator } \\
\text { Politik }\end{array}$ & & \\
1. Tdk konsisten & 85 & 21,3 \\
2. Konsisten & 315 & 78,7 \\
$\begin{array}{l}\text { Pesan Politik } \\
\text { 1. Tdk hierarkis }\end{array}$ & 79 & 19,8 \\
$\begin{array}{l}\text { 2. Hierarkis } \\
\text { Media dan Saluran }\end{array}$ & 321 & 80,2 \\
$\begin{array}{l}\text { 1. Media Massa } \\
\text { 2. Saluran }\end{array}$ & 213 & 53,2 \\
$\quad$ interpersonal & 187 & 46,8 \\
\hline
\end{tabular}


Tabel 1 menunjukkan bahwa sebagian besar (78,7\%) masyarakat pemilih konsisten terhadap komunikator politik, pesan politik yang hierarkis $(80,2 \%)$, sedangkan media massa $(53,2 \%)$ dan saluran interpersonal hampir sama besar persentasenya.

b. Distribusi masyarakat pemilih berdasarkan variabel efek (perilaku memilih masyarakat) di Kecamatan Kota Kefamenanu

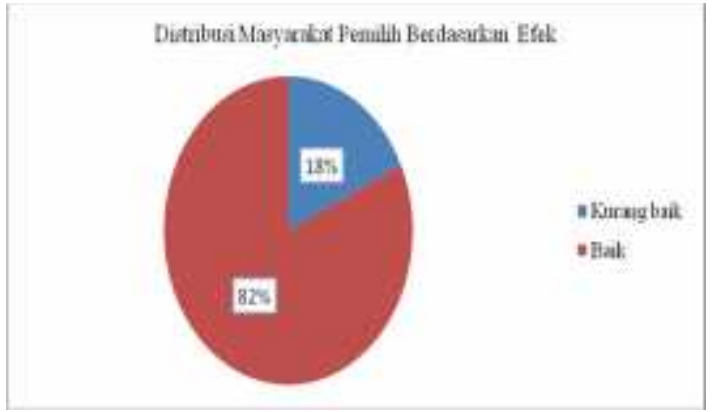

Gambar 1. Distribusi masyarakat pemilih berdasarkan efek (perilaku memilih masyarakat) di Kecamatan Kota Kefamenanu

Berdasarkan gambar 1 menunjukkan bahwa hampir seluruh masyarakat pemilih mempunyai efek (perilaku memilih masyarakat) yang baik $(82 \%)$.

c. Distribusi masyarakat pemilih berdasarkan variabel model pendekatan sosiologis di Kecamatan Kota Kefamenanu

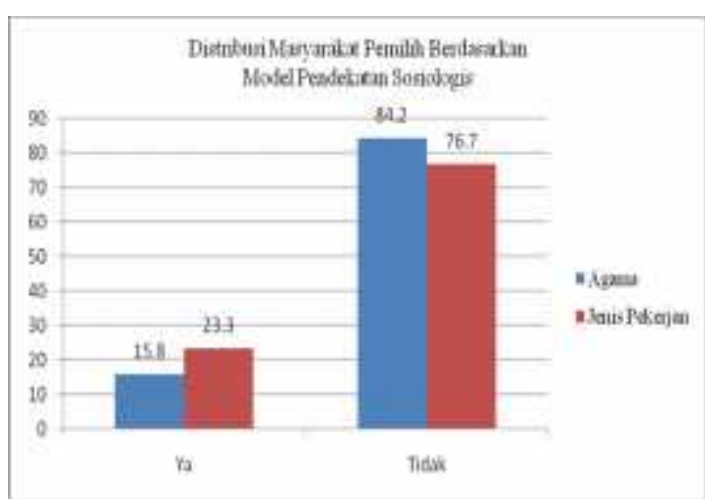

Gambar 2. Distribusi masyarakat pemilih berdasarkan variabel model pendekatan sosiologis di Kecamatan Kota Kefamenanu

Gambar 2 menunjukkan bahwa lebih dari sebagian besar masyarakat di Kecamatan Kota Kefamenanu memilih calon tunggal Pilkada 2015 tidak berdasarkan faktor agama yang dianut $(84,2 \%)$ dan jenis pekerjaan $(76,7)$. Hanya sedikit sekali yang menjadikan kedua faktor tersebut sebagai alasan memilih pasangan calon. 


\section{Analisis Bivariat}

Hasil analisis hubungan variabel independen (komunikator politik, pesan politik, media dan saluran, model pendekatan sosiologis (agama yang dianut dan jenis pekerjaan) dengan variabel dependen yaitu efek (perilaku memilih masyarakat).

Tabel 2. Hubungan antara Komunikator Politik, Pesan Politik, Media dan Saluran, Model Pendekatan Sosiologis (Agama yang dianut dan Jenis Pekerjaan) dengan Efek (perilaku memilih masyarakat)

\begin{tabular}{|c|c|c|c|c|c|c|}
\hline \multirow{3}{*}{\multicolumn{2}{|c|}{ Variabel }} & \multicolumn{4}{|c|}{$\begin{array}{c}\text { Efek (Perilaku Memilih } \\
\text { Masyarakat }\end{array}$} & \multirow{3}{*}{$\begin{array}{l}\text { Nilai } \\
p\end{array}$} \\
\hline & & \multicolumn{2}{|c|}{ Kurang baik } & \multicolumn{2}{|c|}{ Baik } & \\
\hline & & $\mathbf{n}$ & $\%$ & $\mathbf{n}$ & $\%$ & \\
\hline \multicolumn{7}{|c|}{ Kom.Politik } \\
\hline 1. & Tdk konsisten & 49 & 57,6 & 36 & 42,4 & 0,000 \\
\hline 2. & Konsisten & 23 & 7,3 & 292 & 92,7 & \\
\hline \multicolumn{7}{|c|}{ Pesan Politik } \\
\hline 1. & Tdk hierarkis & 54 & 68,4 & 25 & 31,6 & 0,000 \\
\hline 2. & Hierarkis & 18 & 5,6 & 303 & 94,4 & \\
\hline \multicolumn{7}{|c|}{ Media \& Saluran } \\
\hline 1. & Media Massa & 8 & 3,8 & 205 & 96,2 & \\
\hline & $\begin{array}{l}\text { Saluran } \\
\text { personal }\end{array}$ & 64 & 34,2 & 123 & 65,8 & 0,000 \\
\hline \multicolumn{7}{|c|}{ Agama yang dianut } \\
\hline 1. & $\mathrm{Ya}$ & 14 & 22,6 & 48 & 77,4 & \\
\hline 2. & Tidak & 58 & 17,2 & 280 & 82,8 & 0,308 \\
\hline \multicolumn{7}{|c|}{ Jenis Pekerjaan } \\
\hline 1. & $\mathrm{Ya}$ & 16 & 17,2 & 77 & 82,8 & \\
\hline 2. & Tidak & 56 & 18,2 & 251 & 81,8 & 0,820 \\
\hline
\end{tabular}

Berdasarkan tabel 2 maka komunikator politik, pesan politik, media dan saluran mempunyai hubungan signifikan terhadap efek (perilaku memilih masyarakat) yaitu dengan nilai $\mathrm{p}<\alpha(0,05)$, sedangkan model pendekatan sosiologis (agama dan jenis pekerjaan) tidak mempunyai hubungan dengan efek (perilaku memilih masyarakat) yaitu dengan nilai $\mathrm{p}>\alpha(0,05)$.

\section{C.2. PEMBAHASAN}

Berdasarkan hasil penelitian maka dibuat pembahasan yang berhubungan dengan variabel penelitian.

\section{Hubungan komunikator politik dengan efek (perilaku memilih masyarakat)}


Berdasarkan hasil analisis hubungan variabel pada tabel 2 didapatkan ada hubungan yang signifikan antara komunikator politik dengan efek (perilaku memilih masyarakat) dengan nilai $\mathrm{p}<\alpha(0,05)$. Hasil ini di tunjukkan dengan persentase komunikator politik yang konsisten dalam proses pilkada dan memberikan efek baik pada perilaku masyarakat pemilih sebesar $92,7 \%$.

Menurut teori disonansi kognitif yang dibangun dari teori konsisten, yaitu teori yang memandang bahwa manusia selalu merasa nyaman dengan sesuatu yang tetap (konsisten) daripada yang tidak tetap (inkonsistensi). Hal ini sangat berhubungan dengan konsep teori komunikator bahwa dalam settingan politik seorang komunikator politik berperan untuk mempersuasi masyarakat melalui suatu isu atau informasi politik pada konteks peristiwa politik tertentu untuk merubah sikap, persepsi, dan perilaku memilih masyarakat, misalnya dalam pilkada (Nimmo, 2011). Konsep tersebut diperkuat dengan elaboration likelihood theory (ELT) mengenai persuasi komunikator melalui pesan atau isu informasi yang diproses dalam dua jalur, yaitu jalur sentral (memproses informasi dengan pemikiran kritis) dan jalur pinggiran (memproses informasi dengan kurang kritis melalui cara kerja kognitif) (Littlejohn, 2011; McQuial, 2011b).

Hasil penelitian ini, menunjukkan bahwa sebagian besar masyarakat memproses isu informasi atau pesan dari komunikator melalui jalur pinggiran. Masyarakat pemilih di Kabupaten TTU merupakan kelompok masyarakat yang rasional dengan sebagian besar mempunyai latar belakang pendidikan tinggi (SMA, D3 dan PT), sehingga mereka memberikan efek setuju memilih terhadap pasangan calon tunggal berdasarkan karakter dan visi, misi dan program kerja yang disampaikan.

Hasil analisis juga didukung oleh beberapa kutipan pendapat wawancara mendalam dari informan yaitu:

Menurut AK1 dan TM2:

“...Komunikasi politik sangat berjalan yaitu kampanye sesuai jadwal yang ditentukan oleh KPU sendiri, mengkomunikasikan program kerja, visi misi dari pasangan calon yang disebut sebagai paket dubes jilid dua...komunikasi dilakukan secara langsung maupun melalui media massa........sosialisasi di kelurahan dan membangun komunikasi dengan masyarakat".

“...Kami memilih karena tahu persis pasangan calon ini dan program kerja mereka, misalnya dari sisi ekonomi, pembangunan dan pendidikan yaitu Unimor jadi PT negeri, peningkatan SDM melalui pendidikan dan bantuan beasiswa bidikmisi”.

Hasil analisis juga menunjukkan bahwa komunikator politik yang tidak konsisten tapi memberikan efek yang baik $(42,4 \%)$ pada perilaku memilih masyarakat. Menurut 
Maarek dan Wolfsfeld (2003) komunikasi politik merupakan persoalan yang berkaitan dengan konsep komunikasi dan dunia politik yaitu bagaimana pemimpin (pemerintah) berkomunikasi dengan publik, calon kandidat (pasangan calon presiden atau kepala daerah) berkomunikasi dengan masyarakat pemilih dalam memperebutkan hak suara rakyat, berkenaan dengan isu-isu yang ada di tingkat daerah, nasional bahkan internasional dan merujuk pada bagaimana pemimpin-pemimpin tersebut membentuk opini untuk mempengaruhi simpati dan perhatian masyarakat atau diskusi-diskusi publik mengenai isu-isu tertentu.

Efek (perilaku memilih masyarakat) yang baik terhadap komunikasi politik yang disampaikan oleh komunikator politik (pasangan calon tunggal) merupakan proses memperjuangkan berbagai kepentingan publik melalui pesan-pesan verbal dan non verbal serta saling mempengaruhi dengan berbagai kebijakan pemerintah dengan suatu sistem politik. Namun menurut Changara (2014) efek dari komunikasi politik terkadang tidak dapat diprediksi karena kepentingan dari berbagai kelompok masyarakat sulit di rumuskan dan dipetakan dalam pesan-pesan politik yang disampaikan. Sehingga dalam penelitian ini menemukan bahwa efek yang muncul berkaitan dengan komunikator politik itu bervariasi antara lain, efek kurang baik yang muncul dari komunikator politik yang konsisten sebesar 7,3\%, sedangkan yang tidak konsistensi sebesar 57,6\%, dan efek baik $(42,4 \%)$.

\section{Hubungan pesan politik dengan efek (perilaku memilih masyarakat)}

Pesan politik merujuk pada pembicaraan tentang aktivitas politik yang sampai kondisi tertentu membicarakan tentang tiga hal yaitu pembicaraan politik yang berkenaan dengan kekuasaan, pengaruh, dan otoritas (kewenangan) (Nimmo, 2011). Pada penelitian saat ini pesan politik yang sebaiknya disampaikan oleh pasangan calon tunggal meliputi pesan yang berhubungan dengan Pilkada 2015 di Kabupaten TTU. Isi pesan dapat disampaikan pada saat kampanye, sosialisasi dan melalui media atau saluran yang disampaikan secara hierarkis oleh pasangan calon tunggal atau tim suksesnya. Pesan politik direncanakan dan dirancang oleh komunikator politik, kemudian disebarkan dan disampaikan kepada khalayak atau komunikan (masyarakat pemilih).

Hasil penelitian menggambarkan bahwa ada hubungan yang signifikan antara pesan politik dari pasangan calon tunggal dengan efek (perilaku memilih masyarakat) dengan nilai $p<\alpha(0,05)$. Berdasarkan uji analisis hubungan kedua variabel maka pesan politik 
yang disampaikan secara hierarkis memberikan efek baik pada perilaku memilih masyarakat sebesar (94,4\%). Menurut Nimmo (2011) dan Berger (Littlejohn, 2011), proses penyampaian pesan melalui langkah-langkah yang dilalui dalam pesan politik bersifat hierarkis atau berjenjang karena tindakan-tindakan tertentu dibutuhkan lebih dulu agar tindakan lain dapat dilakukan, atau menurut Berger disebut teori rencana. Hal ini karena dipandang bahwa komunikasi merupakan proses penting untuk mencapai tujuan maka perencanaan pesan adalah hal yang vital atau pokok dalam komunikasi.

Menurut teori logika pesan dari O'keefe mengemukakan tentang tiga logika dalam merancang pesan, dimulai dari yang paling tidak terpusat pada orang (least personcentered) hingga pada yang sangat terpusat (most person-centered) yaitu 1) logika ekspresif (expressive logic), merupakan logika yang memandang komunikasi sebagai suatu cara untuk mengekspresikan diri, menyatakan perasaan dan pikiran. Pesan yang terdapat pada logika ekspresif ini bersifat terbuka dan reaktif, dengan hanya memberikan sedikit perhatian pada kebutuhan dan keinginan orang lain; 2) logika konvensional (conventional logic) merupakan logika yang melihat komunikasi sebagai suatu permainan yang dimainkan dengan mengikuti sejumlah aturan. Dalam hal ini, komunikasi dipandang sebagai alat untuk mengekspresikan diri yang dilakukan menurut aturan dan norma yang diterima termasuk hak dan tanggungjawab masing-masing orang yang terlibat; dan 3) logika retorika (rhetorical logic) adalah logika yang memandang komunikasi sebagai suatu cara untuk mengubah aturan melalui negosiasi. Pesan yang dirancang melalui logika ini cenderung lentur atau fleksibel, memiliki pemahaman dan terpusat pada lawan bicara (Littlejohn, 2011 dan Morissan, 2013).

Hal ini juga di dukung oleh beberapa pendapat tentang pesan politik yang disampaikan pasangan calon tunggal yang dikutip dalam proses wawancara mendalam yaitu:

“...........pesan politik yang disampaikan adalah visi, misi dan program kerja dari pasangan calon......namun terkadang pesan tersebut bisa terlaksana dan tidak...karena pengalamannya tidak terlaksana.....misalnya di bidang kesehatan, pendidikan, dan pertanian" (MP1).

"Selama ini pesan politik yang berkembang melalui struktur pemerintah. $R S$ menggunakannya untuk mengkampanyekan visi misinya melalui kepala desa, aparatur negara, dan memanfaatkan RPD........"(AK2). 
Littlejohn (2011) menyatakan bahwa para komunikator (politik) seringkali mendesain pesan melalui berbagai model pesan dengan tujuan untuk menarik perhatian (mempersuasi) dalam situasi tertentu (contohnya dalam pilkada).

Pesan politik yang tidak hierarkis, namun juga memberikan efek yang baik yaitu sebesar $(31,6 \%)$, hal ini kemungkinan karena adanya faktor pemahaman yang baik dari masyarakat pemilih terkait Pilkada. Menurut Ball-Rokeach dan DeFleur (dalam Nimmo, 2010) merumuskan jenis-jenis akibat (effect) potensial komunikasi dalam tiga kategori sebagai berikut: 1) akibat kognitif, merujuk pada pengetahuan komunikan terhadap pesan yang diterima, dan dalam komunikasi politik, menciptakan ambiguitas terhadap informasi yang diperoleh dan diproses dalam keanekaragaman interpretasi yang dapat dibuat khalayak. Kemudian orang dapat memperluas realitas politik yang dipersepsinya melalui perluasan dunia politik melalui peran media dalam menyusun agenda; 2) akibat afektif, merujuk pada pemahaman pesan politik yang diterima dan lebih cenderung diperhitungkan orang dalam menyusun kepercayaan politik daripada nilai politik mereka; dan 3) akibat partisipasi, yaitu keterbukaan terhadap komunikasi politik yang dapat mempengaruhi orang agar secara aktif dapat terlibat dalam politik, di pihak lain, komunikasi politik bisa menekan partisipasi politik.

\section{Hubungan media dan saluran interpersonal dengan efek (perilaku memilih masyarakat)}

McQuail dan Nimmo (2011) mengungkapkan bahwa media adalah "saluran komunikasi atau alat yang memudahkan penyampaian pesan”. Sedangkan dalam konteks politik modern, media massa tidak hanya bagian integral dari politik, tetapi memiliki posisi yang sentral dalam politik, artinya media massa merupakan saluran komunikasi massa yang menyebarluaskan informasi kepada rakyat untuk dapat diketahui dan diskusikan dalam berbagai bentuk forum diskusi publik (Pawito, 2009). Pada penelitian ini yang termasuk dalam media dan saluran adalah media massa (seperti media cetak, media elektronik) dan saluran interpersonal (keluarga, teman, sahabat dan masyarakat lain).

Berdasarkan hasil penelitian diperoleh bahwa ada hubungan yang signifikan antara penggunaan media massa dan saluran interpersonal dengan efek (perilaku memilih masyarakat). Penggunaan media massa yang memberikan efek baik, persentasenya lebih besar $(96,2 \%)$ daripada saluran interpersonal (65,8\%). Dalam Penelitian ini yang termasuk 
dalam media cetak yaitu Koran Pos Kupang, Timor Express dan Victory News, sedangkan media elektronik meliputi radio, televisi dan media online.

Penggunaan media massa yang paling besar untuk mengetahui proses pelaksanaan Pilkada adalah media elektronik, dalam hal ini radio sebesar $(62,4 \%)$, diikuti Koran Pos Kupang (43,7\%) dan Timor Express $(39,4 \%)$, sedangkan Koran Victory News, televisi dan media online persentasenya kecil. Hasil penelitian menunjukkan bahwa pada umumnya masyarakat pemilih di Kabupaten TTU mengetahui proses Pilkada calon tunggal melalui media massa, hal ini berhubungan dengan keberadaan masyarakat yang sudah mengarah pada masyarakat modern yang selalu menggunakan media massa dalam berbagai aktivitas kehidupannya karena lebih mudah dan praktis.

Hal ini sesuai dengan konsep dari McChesney (Cangara, 2014) berpendapat bahwa hampir semua varian teori sosial dan politik menguraikan bahwa sistem media dan komunikasi merupakan landasan dari masyarakat modern. Dalam sistem politik tertentu, mereka (sistem media dan komunikasi) melayani dan membantu proses demokrasi. Artinya media massa merupakan sumber utama dalam berbagai aktivitas dan peristiwa politik yang dapat diketahui. Media massa melaporkan dan menyebarluaskan berbagai peristiwa politik, tentang berbagai pendapat dan pikirian-pikiran pemimpin politik, pernyataan yang di sampaikan, calon kandidat kepala daerah, strategi mereka dalam memenangkan pilkada, visi dan misi, janji-janji yang akan mereka lakukan setelah terpilih menjadi pejabat nasional atau daerah, kampanye pemilu yang akan mereka gelar, kemampuan mereka berdebat melalui ruang dan tempat yang disediakan media, dan sebagainya.

Menurut Valkenburg dan Petter (2013), media massa masih menjadi sumber utama bagi komunikasi politik dan hal ini seringkali membuat persepsi dan interpretasi seseorang bekerja dalam cara kognitif yang kreatif dan berhubungan langsung dengan keadaan sosialnya. Hasil ini juga didukung dengan beberapa kutipan wawancara dari informan (MP2, MP4, MP5, AP3, TM1, TM2, TM3, AK1, dan AK2) sebagai berikut:

“Kami tahu pasangan calon tunggal dari media massa....sedangkan media lokal yaitu $R P D$, tapi itu bagi yang mempunyai radio, selain itu TV Biinmafo tapi jangkauannya terbatas.......sedangkan anak-anak muda kebanyakan media online........."

“...........Media lokal NTT lain yaitu Timex, Pos Kupang, dan Victory news yang cukup berperan dalam menyalurkan informasi politik berkaitan dengan pilkada TTU saat ini............".

"Sedangkan media nasional seperti kompas atau tempo, biasanya masyarakat tertentu saja tapi jarang. Begitu pun juga media elektronik seperti televisi seperti metro, rcti dan tvone......ada juga kampanye melalui iklan”. 
Iklan kampanye adalah penyampaian pesan kampanye melalui media cetak dan elektronik berbentuk tulisan, gambar, animasi, promosi, suara, peragaan, sandiwara, debat, dan bentuk lainnya yang dimaksudkan untuk memperkenalkan pasangan calon atau meyakinkan pemilih, yang di fasilitasi oleh KPU Provinsi/KIP Kabupaten/Kota yang didanai Anggaran Pendapatan dan Belanja Daerah (PKPU Nomor 7 Tahun 2015).

Penggunaan Koran Pos Kupang persentasenya cukup besar kedua, hal ini sesuai dengan penelitian oleh Yusuf (2012) mengenai peran media lokal dalam konstelasi komunikasi politik di daerah yaitu media lokal sangat berpengaruh pada tiga level yaitu level mikro, meso dan makro. Pada level mikro merujuk pada produk media berupa isi atau teks media yang secara sederhana terlihat dari objektivitas yang disajikan, level meso meliputi dinamika manajerial perusahan pers yang sehat secara ekonomi dan bisnis serta level makro yang mencakup aturan dan undang-undang yang jelas bagi pers lokal yang mengartikan fungsinya. Selain itu faktor idealisme yang terkait dengan partisipasi dan konsistensi media sebagai pemantauan kekuasaan di daerah guna untuk menciptakan good local goverenment, yaitu menjamin adanya partisipasi, transparansi, dan akuntabilitas di daerah.

Proses komunikasi tidak selalu menimbulkan efek yang diharapkan dan dapat menemukan pengaruh yang signifikan, khusus efek dari media massa terhadap opini dan sikap. Hal ini didukung oleh pendapat dari McQuail (2011b) yaitu bahwa seseorang (dalam penelitian saat ini adalah masyarakat pemilih) mempunyai banyak informasi atau persepsi yang diterima melalui media, yang bisa berbentuk gambar ataupun suara tetapi mereka belum mengetahui secara pasti efek atau perubahan yang akan terjadi akibat media tersebut, khususnya terhadap efek memilih masyarakat kepada pasangan tunggal, sehingga dapat dikatakan bahwa media bukan satu-satunya alat penyebab timbulnya efek.

Selain media massa, saluran interpersonal dalam hal ini termasuk tokoh masyarakat, aktivis politik, akademisi, keluarga, teman dan masyarakat pemilih mempunyai persentase yang kecil. Hasil penelitian ini berbeda dengan teori Lazarsfeld mengenai Two-step flow of communication yaitu bahwa pesan (misalnya pesan politik) ditransmisikan melalui media massa (radio, cetak, elektronik) kepada pemimpin opini (tokoh masyarakat, aktivis politik, dan akademisi) dan dari mereka baru ke masyarakat pemilih atau ke masyarakat pada umumnya (Laughey, 2007). Sehingga pesan politik yang diterima oleh masyarakat pemilih dari media massa belum melalui proses seleksi oleh pemimpin opini. 
Pesan politik dari media massa yang secara langsung diketahui oleh masyarakat pemilih, hal ini sesuai dengan konsep menurut Brants and Voltmer (2011) bahwa 'komunikasi politik kontemporer dapat dilihat dalam dua dimensi yaitu 'dimensi horizontal sebagai 'mediatization' dan dimensi vertikal sebagai 'de-centralization' yang sangat berkaitan erat'. Dimenisi horizontal 'menggambarkan hubungan antara politisi (para politikus, atau lembaga politik terkait) dan media (jurnalis dan media massa) - yaitu, para elit komunikasi politik yang bersama-sama, tetapi juga bersaing satu sama lain, menciptakan dan menyebarkan pesan-pesan politik untuk konsumsi massa'. Sedangkan dimensi vertikal 'menunjukkan interaksi antara dua elit komunikasi politik di satu sisi, dan warga sebagai penerima akhir dari pesan-pesan ini di sisi lain'. Bersama dua dimensi perubahan mencakup hubungan segi tiga antara aktor-aktor politik, media dan penonton yang sebelumnya telah dijelaskan dalam ruang sosial dan kelembagaan komunikasi politik (Brants dan Voltmer, 2011). Dengan demikian pesan politik tersebut dapat memberikan efek yang tidak dapat diprediksi dalam hal ini bisa menimbulkan efek baik dan kurang baik.

Hal ini didukung dengan hasil wawancara dari informan (MP1) yaitu:

"Kita dengar dari orang tua atau tokoh-tokoh masyarakat saat di Gereja bahwa hari ini ada kampanye......".

Penyampaian pesan melalui orang tua atau tokoh masyarakat merupakan salah satu saluran informasi, hal ini sesuai dengan pendapat menurut Burke (dalam Nimmo, 2011) bahwa manusia adalah saluran sekaligus sebagai makhluk pencipta dan pemakai lambang atau simbol untuk melancarkan atau saling tukar menukar pesan, dan selanjutnya, manusia membutuhkan transmisi media (media massa) yang dapat mengirimkan dan menyebarkan pesan di berbagai tempat yang jauh dan beragam. Kontak langsung yang dilakukan oleh pasangan calon, didukung oleh pendapat menurut Katz (1957) yang mengatakan bahwa kontak pribadi tampaknya lebih sering dan efektif daripada media massa dalam mempengaruhi keputusan pemberian hak suara.

Hasil penelitian Mutz dan Martin (2001), menunjukkan bahwa meskipun kurang beragamnya perspektif berita media Amerika, namun mereka menemukan individu yang terkena pandangan politik tertentu kurang berpengaruh dengan terpaan media dibandingkan dengan diskusi politik interpersonal. Media hanya berguna sebagai sumbersumber informasi yang relatif sulit dan sangat rendah untuk melakukan pengaruh mengingat sifat impersonal dari media massa. 
Dengan demikian dapat dikatakan bahwa dari hasil analisis secara statistik media dan saluran yang mempunyai hubungan signifikan dengan efek tapi kenyataannya di tempat penelitian, beberapa masyarakat pemilih mempunyai pendapat yang berbeda-beda. Ada pendapat yang mendukung namun sebaliknya ada yang memberikan pendapat dan persepsi lain terhadap media dan saluran sesuai dengan kondisi yang mereka alami. Menurut Katz (2015), media dan komunikasi interpersonal tidak dalam kompetisi, melainkan terhubung erat.

\section{Hubungan model pendekatan sosiologis (agama yang dianut dan jenis pekerjaan) dengan efek (perilaku memilih masyarakat)}

Berdasarkan hasil analisis bivariat pada tabel 10 maka diperoleh tidak ada hubungan antara model pendekatan sosiologis (agama yang dianut dan jenis pekerjaan) dengan efek (perilaku memilih masyarakat) dengan nilai $\mathrm{p}>\alpha(0,05)$. Mayoritas masyarakat pemilih di Kabupaten TTU beragama Katolik. Sedangkan distribusi pekerjaan, mayoritas masyarakat pemilih bekerja baik sebagai PNS, pegawai swasta, buruh, petani, pedagang dengan persentase sebesar $(89,3 \%)$.

Hasil ini didukung dengan beberapa pendapat dalam wawancara yaitu:

"Pengalaman saya bahwa dalam proses pemilihan di tingkat Presiden, DPR, dan kepala daerah khususnya di TTU faktor agama tidak mempengaruhi untuk memilih figur atau calon tertentu" (MP1).

"Faktor agama mungkin tidak terlalu berpengaruh karena kita disini mayoritas katolik sehingga isu agama tidak terlalu relefan kecuali ketika pasangan calon ada yang beragama lain maka akan relevan karena di TTU selama ini dan kebetulan pasangan calon banyak beragama Katolik.....namun bagi minoritas kadang menimbulkan kecemburuan, misalnya ijin mendirikan tempat ibadah dan sebagainya" (MP4, AK1, AP1, TM1).

Pendapat lain yang berbeda tentang faktor agama terkait efek yaitu:

"Faktor agama tidak berpengaruh dalam perilaku memilih masyarakat Kefa. Namun pada pilkada gubernur dua tahun lalu kami pilih pak Eston karena ini bukan pemilihan uskup. Ya betul jadi ada peran elit agama dalam proses pilkada ini. Ada Romo NL di Insana yang punya peran sentral dalam proses pilkada” (MP2).

"Faktor agama tidak berpengaruh karena semua beragama katolik. Tapi yang kami tidak setuju adalah struktur agama katolik terlalu jauh terlibat langsung mendukung RS, dan saya menantang itu. Minoritas di sini khususnya protestan juga tidak setuju karena ada beberapa gereja misalnya di Noemuti di cabut ijinnya dan dipaksakan untuk tidak melanjutkan pembangunan" (AK2).

Sedangkan terkait dengan faktor pekerjaan, beberapa informan mengatakan bahwa: 
"Faktor pekerjaan tidak memihak kepada siapa pun, entah itu ke keluarga, ke partai politik pengusung calon tersebut.......namun kalau PNS mungkin ada tapi tidak kelihatan" (MP1, MP2, TM2).

Hasil penelitian baik secara statistik maupun berdasarkan wawancara untuk beberapa informan berbeda dengan teori pendekatan sosiologis dari Denver yaitu karakter sosial dan pengelompokan sosial, dalam hal ini faktor agama yang dianut dan jenis pekerjaan mempunyai pengaruh yang cukup signifikan dalam menentukan perilaku memilih seseorang (Asfar, 2006). Pengaruh pendekatan sosiologis ini juga diperkuat oleh penelitian dari Gaffar (1992) yang menyatakan bahwa ada pola hubungan yang kuat antara orientasi agama pemilih dengan partai yang dipilih. Penelitian lain juga dilakukan oleh Rohi dan Adoe et al.,(2015) dalam pemilihan legislatif Tahun 2014 di Provinsi NTT menemukan bahwa ada pengaruh kesamaan identitas agama, status sosial dan kedaerahan dalam perilaku memilih masyarakat provinsi NTT secara keseluruhan. Penelitian dengan metode kualitatif dan wawancara mendalam tersebut menemukan bahwa perilaku memilih dan proses pemberian hak suara oleh masyarakat seringkali dipengaruhi oleh tiga faktor utama tersebut.

Beberapa informan mengatakan faktor agama dan jenis pekerjaan berpengaruh terhadap efek memilih masyarakat. Hal ini selaras dengan penelitian beberapa ahli yang menemukan bahwa ada hubungan kuat antara latar belakang agama pemilih dengan pilihan partai politik yang beragama sama. Pemilih yang beragama Islam cenderung memilih partai Islam. Begitu juga dengan orientasi agama yang mana pemilih santri cenderung memilih partai Islam. Sementara pemilih yang beragama non-Islam cenderung memilih partai nasionalis. Adanya pengaruh aliran politik di Indonesia masih relatif berlaku untuk menjelaskan perilaku memilih masyarakat Indonesia modern (Mallarangeng, 1997; King, 2003; Ananta et al., 2004). Sedangkan menurut Lipset (1981) menjelaskan lebih jauh bahwa karakteristik sosiologis perilaku pemilih yang menekankan pada status sosial dapat juga dipengaruhi oleh beberapa indikator yaitu pendapatan, pendidikan, ras, tempat tinggal, situasi, status, dan organisasi.

Pendapat maupun persepsi masyarakat pemilih dari berbagai kalangan yang bervariasi tentang ada dan tidaknya pengaruh faktor agama dan jenis pekerjaan, menggambarkan bahwa masih terjadi ketidakadilan atau faktor kekuasaan politik dari pemimpin politik di suatu daerah sehingga berdampak pada masyarakat, dan dalam hal ini terkait dengan pelaksanaan Pilkada yang membuat masyarakat takut dan berada dibawah 
tekanan untuk harus memilih pemimpin politik tersebut, karena kalau tidak akan mendapat konsekuensi terhadap agama dan pekerjaan masyarakat tersebut.

\section{Simpulan}

1. Komunikator politik dari pasangan calon tunggal Pilkada Kabupaten TTU mempunyai hubungan yang signifikan dengan efek (perilaku memilih masyarakat).

2. Pesan politik dari pasangan calon tunggal Pilkada Kabupaten TTU mempunyai hubungan yang signifikan dengan efek (perilaku memilih masyarakat).

3. Media dan saluran komunikasi interpersonal dari pasangan calon tunggal Pilkada di Kabupaten TTU mempunyai hubungan yang signifikan dengan efek (perilaku memilih masyarakat).

4. Model pendekatan sosiologis (agama yang dianut dan jenis pekerjaan) tidak mempunyai hubungan dengan efek (perilaku memilih masyarakat).

\section{E. Saran}

Saran kepada peneliti lain adalah melakukan penelitian lanjutan dengan tema yang sama namun menggunakan metodologi penelitian kualitatif, untuk memperkaya hasil temuan data yang beragam di lapangan. Selain itu juga, penelitian lanjutan dapat dilakukan terkait dengan variabel model pendekatan sosiologis di tempat lain dengan karakteristik masyarakat pemilih yang berbeda.

\section{Daftar Pustaka:}

Ananta, A. Evi, N. A. \& Leo, S. 2004. Indonesia Electoral Behaviour. Singapura: ISEAS.

Asfar, M. 2006. Pemilu dan Perilaku Memilih 1955-2004. Surabaya: Eureka.

Brants, Kees. \& Voltmer, Katrin. 2011. Political Communication in Postmodern Democracy; Challenging the Primacy of Politics. New York. PALGRAVE MACMILAN.

Gaffar, A. 1992. Javanese Voters: A case Study of Election Under a Hegemony Party System. Yogyakarta: Gadjah Mada University Press.

Higashikata, T. \& Kawamura, K. 2015. Voting Behavior in Indonesia from 1999 to 2014. Ide Discussion Paper No. 512.

Katz, E. 1957. Two-Step Flow of Communication: An Up-To-Date Report on an Hypothesis. Political Opinion Quarterly Vol. 21, no. 1: 61-78. 
Katz, E. 2015. Where Are Opinion Leaders Leading Us?. International Journal of Communication Vol. 9: 1023-1028.

King, D. Y. 2003. Half-Heart: Electoral Institutions and Struggle for Democracy in Indonesia. Westport: Conn: Praegar.

Laughey, D. 2007. Key Themes in Media Theory. New York: McGrawHill.

Lipset, S. M. 1981. Political Man: The Social Bases of Politics. New York: Doubly Anchor Books.

Littlejohn, W. S. \& Foss, A. K. 2011. Theories of Human Communication (Tenth Edition). Long Grove, Illinois: Waveland Press Inc.

Maarek, J. P. \& Wolfsfeld, G. 2003. Political Communication In A New Era; A Crossnational perspective. London: Routledge.

Mallarangeng, A. A. 1997. Contextual Analysis on Indonesian Electoral Behavior. Dissertation, Nothern Illinois University, Unpublished.

McQuail, D. 2011b. Teori Komunikasi Massa (Buku 2 edisi 6. Terj. Putri Izzati). Jakarta: Salemba Humanika.

Morissan. 2013. Teori Komunikasi; Komunikator, Pesan, Percakapan, dan Hubungan (Interpersonal). Jakarta: Ghalia Indonesia.

Mutz, D. C. \& Martin, P. S. 2001. Facilitating Communication across Lines of Poltical Difference: The Role of Mass Media. American Political Science Review. Vol. 95, no. 2: $97-114$.

Nimmo, D. 2010. Komunikasi Politik; Khalayak dan Efek (Terj. Tjun Surjaman). Bandung: PT. Remaja Rodakarya.

Nimmo, D. 2011. Komunikasi Politik; Komunikator, Pesan, dan Media (Terj. Tjun Surjaman). Bandung: PT. Remaja Rosdakarya.

Pawito. 2009. Komunikasi Politik; Media Massa dan Kampanye Pemilihan. Yogyakarta: Jalasutra.

Rohi, R. \& Adoe, M. 2015. Evaluasi Pemilu Legislatif 2014: Jawa Tengah, Jawa Timur, DI Yogyakarta, Nusa Tenggara Timur, Aceh, Papua, Kalimantan Selatan, DKI Jakarta, Sulawesi Utara, dan Sulawesi Selatan. Jakarta: Institut Riset Kepemiluan LIPI.

Singarimbun, M. \& Effendi, S. 1989. Metode Penelitian Survei. Jakarta: LP3ES.

Sugiyono. 2009. Metode Penelitian Kuantitatif, Kualitatif, dan $R \& D$. Bandung: Alfabeta.

\section{Peraturan:}


Undang-undang Nomor 8 Tahun 2012 Tentang Penyelengaraan Pemilihan Umum Anggota Dewan Perwakilan Rakyat, Dewan Perwakilan Daerah, dan Dewan Perwakilan Rakyat Daerah;

Undang-undang Nomor 8 Tahun 2015 tentang Pemilihan Gubernur, Bupati, dan Walikota;

\section{Jurnal:}

Valkenburg, M. P. \& Petter, J. 2013. Five Challenges for the Future of Media-Effects Research. International Journal of Communication, Vol. 7, no. 2: 197-215.

Website. 2015. Undang-undang nomor 1 tahun 2015. http://www.dpr.go.id. Diakses 12 September 2015.

Yususf, I. A. 2012. Media Lokal dalam Konstelasi Komunikasi Politik di Daerah. Yogyakarta: Jurnal Ilmu Sosial dan Ilmu Politik. Vol. 14, no. 3: 297-316.

\section{Internet:}

Media online. 2015. Topik Pilihan; Pilkada Serentak. http://www.m.kompas.com, diakses 30 Agustus 2015.

Media online. 2015. MK Putuskan Calon Tunggal Tetap Mengikuti Pilkada Serentak. http://www.m.kompas.com, diakses 29 September 2015. 